Article

\title{
Social Sustainability Assessment in Livestock Production: A Social Life Cycle Assessment Approach
}

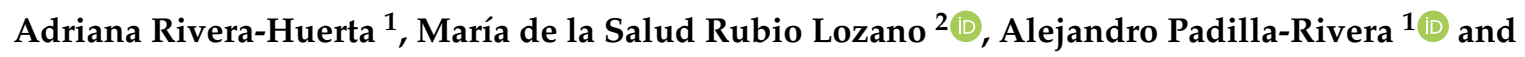 \\ Leonor Patricia Güereca ${ }^{1, *}$ (D) \\ 1 Instituto de Ingenieria, Universidad Nacional Autónoma de México, Ciudad de Mexico 04510, Mexico \\ 2 Facultad de Medicina Veterinaria y Zootecnia, Universidad Nacional Autónoma de México, \\ Ciudad de Mexico 04510, Mexico \\ * Correspondence: LGuerecaH@iingen.unam.mx; Tel.: +52-55-5623-3601
}

Received: 15 May 2019; Accepted: 11 August 2019; Published: 15 August 2019

\begin{abstract}
This study evaluates the social performance of monoculture (MC), intensive silvopastoral (ISP), and native silvopastoral (NSP) livestock production systems in the tropical region of southeastern Mexico through a social life cycle assessment (SCLA) approach. The methodological framework proposed by the United Nations Environmental Program/Society of Environmental Toxicology and Chemistry (UNEP/SETAC) (2009) was employed based on a scoring approach with a performance scale ranging from 1 (very poor) to 4 (outstanding). Twelve livestock ranches for calf production were evaluated using 18 impact subcategories associated with the categories "human rights", "working conditions", "health and safety", "socioeconomic repercussions", and "governance". The stakeholders evaluated were workers, the local community, society, and value chain actors. The ranches had performance scores between 1.78 (very poor) and 2.17 (poor). The overall average performance of the ranches by production system was $1.98,1.96$, and 1.97 for the MC, ISP, and NSP systems, respectively. The statistical analysis shows that there is no significant difference in the social performance of the livestock production systems. This assessment indicates that the cattle ranches analyzed in Mexico have poor or very poor social performance. The results show that socioeconomic and political contexts exert a greater influence on the social performance of livestock production systems than does their type of technology.
\end{abstract}

Keywords: social sustainability; livestock production systems; social life cycle assessment; tropical livestock; monoculture; silvopastoral

\section{Introduction}

Animal husbandry is an activity with important positive social and economic effects. Livestock systems contribute $40 \%$ to global agricultural GDP [1] and are organized in long market chains that employ at least 1.3 billion people globally and directly support the livelihoods of 600 million smallholder farmers in the developing world [2,3]. At the same time, livestock is an important source of nourishment. Livestock products contribute $17 \%$ to global kilocalorie consumption and $33 \%$ to global protein consumption [2]. Mexico is one of the countries with the highest number of livestock; in 2017 , it accounted for $2.2 \%$ of the global population and ranked ninth in the number of livestock $(33,918,906)[4]$.

In Mexico, animal husbandry is an activity that takes place throughout the country; however, the tropical region stands out, having $33 \%$ of the population of national cattle $[5,6]$. In the tropical region, livestock production is characterized by the use of grazing under two predominant systems: the traditional or native system and the monoculture (MC) system. Recently, silvopastoral systems have 
been introduced in this region because they have been shown to be potentially more productive than the predominant grazing systems, increasing the biological and economic efficiency of livestock [7].

To date, several studies on grazing systems have been conducted, showing and comparing their environmental impacts [8-12]. However, analyses of livestock systems in developing countries generally overlook or downplay the social contribution or impacts made by this sector. In this sense, the social functions of cattle raising are important; in this regard, the problem consists of obtaining values that show the social contribution made by the livestock sector and that are based on sound principles $[13,14]$.

Therefore, researchers and policy advisers face the difficulty of agreeing on which social functions are important. Understanding the social and socioeconomic characteristics of different livestock production systems are fundamental for the creation of policy and planning instruments that promote the shift towards sustainable systems [15].

Social life cycle assessment (SLCA) evaluates the social impacts of a product or service throughout its life cycle with the aim of protecting human dignity and well-being [16] and supporting decision makers in selecting products that are socially acceptable [17]. SLCA is based on the life cycle assessment (LCA) framework [18,19], and the methodology is holistic, systemic, and rigorous in regard to accessing information about the potential and real impacts of a product's life cycle. Thus, this tool is useful for results communication, supporting decision makers in developing public policies, and in selecting products, inputs, and processes that are socially acceptable [17] and supporting the transition of production systems towards sustainability. Therefore, this methodology is considered an appropriate framework for evaluating the social performance of livestock. Previously, Revéret et al. [20] and Chen and Holden [21] analyzed the socioeconomic impacts of the milk production sector in Canada and Ireland, respectively, using SLCA. In this article, SLCA is adapted for the first time to the livestock sector in Mexico.

The main goal of this study is to analyze the three most relevant livestock production systems in the Mexican tropics through SLCA, for which specific data were used. Through this study, we seek to identify the critical points of animal husbandry from the social dimension of sustainability and to identify which system has the best performance.

\section{Materials and Methods}

The study involves four steps that were performed in alignment with the SLCA methodology and followed ISO 14040/44 [18,19]: (1) the definition of the goal and scope, (2) life cycle inventory analysis, (3) impact assessment, and (4) interpretation

\subsection{Definition of the Goal and Scope}

The goal of this SLCA was to assess the social implications associated with three livestock production systems over their life cycle [17].

This paper adopts a SLCA approach without considering a complete cradle-to-grave system. Importantly, there are different boundaries of SLCA, as found in the systematic review performed by Petti et al. [22]. Of the 35 papers reviewed, $24 \%$ focus on the gate-to-gate approach [23-25], while only $32 \%$ evaluate a cradle-to-grave system product. Therefore, in this study, the system boundaries were from the gate to the gate of the farm and consider the cow-calf system, which includes the reproductive management of cattle, pregnancy and calving, as well as lactation and the weaning of the calf (Figure 1). 


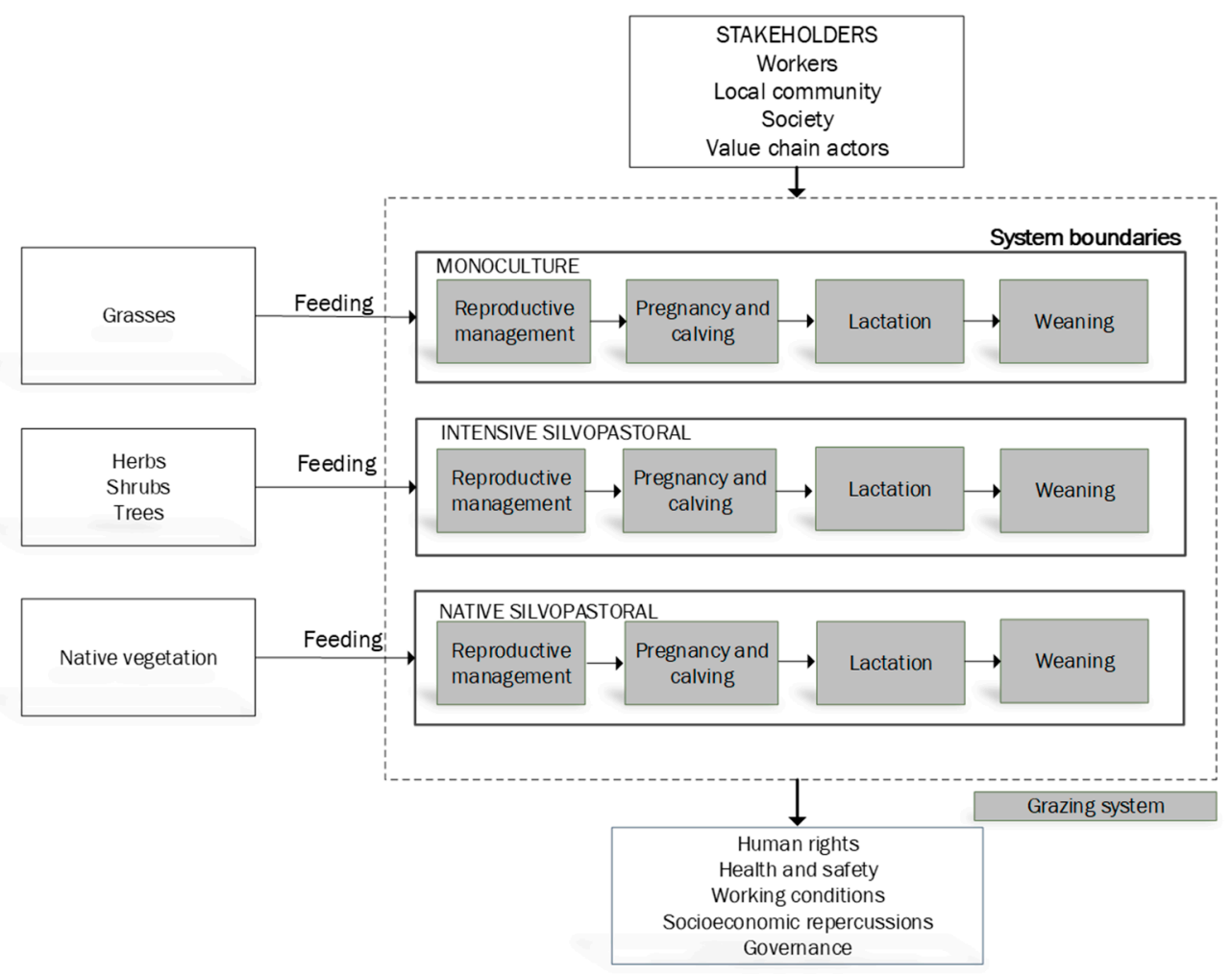

Figure 1. System description.

For the purposes of this study, three grazing livestock systems, the monoculture (MC), intensive silvopastoral (ISP), and native silvopastoral (NSP) systems, were analyzed in two states of the Mexican tropics, Veracruz (V) and Yucatan (Y), with information from 2014 and 2015 collected. This study was based on 12 private cow-calf ranches: three MC, five ISP, and four NSP ranches.

In the Mexican tropics, calf production is characterized by cow-calf herds (Bos indicus $\times$ Bos taurus) maintained on tropical pasture. Nonetheless, there is considerable variability in the management strategies of pasture and supplementation. The main characteristics of the livestock systems studied are mentioned below.

The MC system is characterized by the use of cultivated grasses as the main diet of livestock plus a commercial supplement. The ISP system includes cultivated grasses and legumes, such as Leucaena leucocephala, as the basis of the diet, which is also complemented with commercial concentrate. Finally, the NSP system is characterized by the presence of little infrastructure, and the diet is based on native vegetation; grazing is carried out in the forest (Figure 1). The ranches analyzed are considered medium-sized producers. The herd is composed of cows, heifers and bulls; on average, the MC, ISP, and NSP ranches have 75, 23, and 2, 95, 19, and 2, and 47,9, and 1 heads per type of animal, respectively. All ranches evaluated produce calves; however, one out of four ISP ranches and two out of five NSP ranches are dual purpose (i.e., produce calves and milk). The MC, ISP, and NSP ranches consist of, on average, 145, 96, and 74 ha of land, respectively. The average number of workers per system is 4 , 4 , and 3 for the MC, ISP, and NSP systems, respectively. The calves produced in the three systems studied are sold to cattle fattening farms located in different regions of the country.

To collect data on the operation of each livestock system, face-to-face interviews were conducted with the managers of each of the 12 ranches. Semi-structured face-to-face interviews were also conducted with each of the workers present at the time of the visits. In some ranches, it was not possible to interview all of the workers because they were in remote areas within the ranch or were on their day off; thus, a total of 25 out of 40 workers were interviewed. The total number of workers 
interviewed at each ranch are presented in Table S2 (see supplementary). Additionally, a total of 508 residents of the local communities were surveyed.

In this analysis, the results are not related to a functional unit because there is no direct correlation [26]. However, for communication purposes, $1 \mathrm{~kg}$ of live calf is established as the functional unit, which has been used by other authors in LCA studies [11,27]. The assessment took place in the tropical region of southeastern Mexico in the states of $\mathrm{V}$ (in the municipalities of Ursulo Galvan and San Andres Tuxtla) and Y (in the municipalities of Tizimin, Tzucacab, and Merida). V is the main cattle-producing state in Mexico, with $11 \%$ of the national inventory of cattle [6], while $Y$, over the last five decades, has deforested $29 \%$ of its land due to the increase in the use of livestock land [28]. Therefore, promoting sustainable livestock systems is desired.

\subsection{SLCA Inventory Analysis}

The data collection consisted of designing questionnaires and conducting surveys and interviews. The questionnaires were customized for the workers, the local community, the value chain actors and the managers of the ranches. They included closed-ended (yes/no) questions, multiple choice questions and open-ended questions through which semiquantitative or quantitative data were collected. The questionnaires were completed through surveys and face-to-face interviews with the stakeholders.

\section{Determination of Impact Categories, Subcategories, and Data Sources}

This study included 18 impact subcategories associated with five impact categories: "human rights", "working conditions", "health and safety", "socioeconomic repercussions", and "governance" (Table 1). Four stakeholder groups were selected: workers (permanent employees of the ranches), the local community (people living in the communities closest to the ranches), society (people living in the states of $\mathrm{V}$ and $\mathrm{Y}$ ), and value chain actors (suppliers of inputs and buyers of calves from the ranches).

\subsection{Social Life Cycle Impact Assessment}

After completing the social life cycle inventory data collection, the next step is to determine whether the data indicate good or poor social performance with regard to the specific social aspect. According to the United Nations Environmental Program/Society of Environmental Toxicology and Chemistry (UNEP/SETAC) [17], inventory data can be evaluated and interpreted using a scoring system. The evaluation of social impacts was based on the scoring approach method proposed by Padilla-Rivera et al. [29], to which specific rating criteria were incorporated by subcategory of impact for the allocation of performance value.

To evaluate the social impacts of livestock, social life cycle impact assessment (SLCIA) is the criterion for assigning performance values that are specific to each subcategory based on national and international regulations (see supplementary Table S1). The subcategories "freedom of association and collective bargaining", "social benefits/social security", "job satisfaction", and "social acceptance" were characterized by estimating the percentages of the values collected for these subcategories and classifying the percentages as $0-33 \%, 33-66 \%$ and $66-100 \%$ [30]. According to this scoring system, if the percentage is greater than $66 \%$, then the performance is rated as 3 (acceptable/yellow).

For semiquantitative indicators with yes/no responses, the "acceptable" rating (3) was allocated when the response values met the established reference value (RV) (see supplementary Table S1); a "poor" value (2) was assigned when the RV was not met. If, in addition to not meeting the RV, the ranch carried out practices (commercial or labor) that are detrimental with respect to the indicator, then it was assigned the "very poor" value (1). The highest value was allocated when the ranches presented at least one proactive practice with respect to the $\mathrm{RV}$, reflecting the company's interest in the indicator. 
Table 1. Categories and subcategories of social impact evaluation and social inventory indicators, with the reference framework specified.

\begin{tabular}{|c|c|c|c|}
\hline Impact Categories & Impact Subcategories & Inventory Indicators & Reference Framework \\
\hline \multirow[t]{4}{*}{ Human rights } & Child labor (W) & Number of people under 15 working & $\begin{array}{l}\text { ILO, Convention No. } 138 \text { [31] } \\
\text { UN Global Compact, Principles } 1 \text { and } 5 \text { [32] } \\
\text { ILO Convention No. } 184 \text { [33] }\end{array}$ \\
\hline & \multirow{2}{*}{ Equal opportunities/discrimination (W) } & Number of incidents of discrimination & \multirow{2}{*}{ CEDAW [34] } \\
\hline & & Percentage of working women & \\
\hline & Freedom of association and collective bargaining (W) & $\begin{array}{l}\text { Percentage of workers who are members } \\
\text { of a labor union }\end{array}$ & $\begin{array}{l}\text { ILO, Convention No. } 11 \text { [35] } \\
\text { ILO, Convention No. } 87 \text { [36] } \\
\text { UN Global Compact, Principle } 3 \text { [32] } \\
\text { ILO, Convention No. } 141 \text { [37] }\end{array}$ \\
\hline \multirow{3}{*}{ Health and safety } & \multirow{2}{*}{ Health and safety $(\mathrm{W})$} & Number of work accidents & \multirow{2}{*}{$\begin{array}{l}\text { ILO, Convention No. } 155 \text { [38] } \\
\text { ILO, Convention No. } 184 \text { [33] } \\
\text { LFT [39] }\end{array}$} \\
\hline & & $\begin{array}{l}\text { Presence of a formal policy concerning } \\
\text { health and safety }\end{array}$ & \\
\hline & Safe and healthy living conditions (Lc) & $\begin{array}{l}\text { Number of programs to improve the } \\
\text { health or safety of the community }\end{array}$ & $\begin{array}{c}\text { ISO:26000 [40] } \\
\text { UN Global Compact, Principle } 1 \text { [32] } \\
\text { IFC Performance Standard } 4 \text { [41] }\end{array}$ \\
\hline \multirow[t]{5}{*}{ Working Conditions } & Fair salary $(\mathrm{W})$ & $\begin{array}{l}\text { Average household income per capita } \\
\text { from the income of the worker }\end{array}$ & WB [42] \\
\hline & Working hours (W) & Average number of hours worked/week & $\begin{array}{l}\text { ILO, Convention No. } 30 \text { [43] } \\
\text { ILO, Convention No.184 [33] } \\
\text { LFT [39] }\end{array}$ \\
\hline & Forced labor $(\mathrm{W})$ & $\begin{array}{l}\text { Number of hours of forced labor } \\
\text { identified during the study period }\end{array}$ & $\begin{array}{c}\text { ILO, Convention No. } 105 \text { [44] } \\
\text { UN Global Compact, Principle } 4 \text { [32] }\end{array}$ \\
\hline & Social benefits/social security $(\mathrm{W})$ & $\begin{array}{l}\text { Average percentage of workers who } \\
\text { receive the minimum social benefits } \\
\text { established by law (vacation, days off, } \\
\text { Christmas bonus, social security, flexible } \\
\text { hours, written contract, and training) }\end{array}$ & LFT [39] \\
\hline & Job satisfaction $(\mathrm{W})$ & $\begin{array}{l}\text { Percentage of workers who would } \\
\text { change jobs }\end{array}$ & ORC International [45] \\
\hline
\end{tabular}


Table 1. Cont.

\begin{tabular}{|c|c|c|c|}
\hline Impact Categories & Impact Subcategories & Inventory Indicators & Reference Framework \\
\hline \multirow[t]{4}{*}{ Governance } & Community engagement (Lc) & $\begin{array}{l}\text { Existence of a mechanism to receive and } \\
\text { take into account the opinion of the } \\
\text { community }\end{array}$ & $\begin{array}{l}\text { ISO:26000 [40] } \\
\text { IFC Performance Standard } 4 \text { [41] }\end{array}$ \\
\hline & Public commitments to sustainability issues (S) & $\begin{array}{l}\text { Presence of documents concerning } \\
\text { agreements on sustainability issues } \\
\text { available to the public }\end{array}$ & $\begin{array}{l}\text { ISO:26000 [40] } \\
\text { IFC Performance Standard } 4 \text { [41] }\end{array}$ \\
\hline & Fair competition $(\mathrm{Vc})$ & $\begin{array}{l}\text { Documented declaration or procedures } \\
\text { (policies, strategies, etc.) to avoid } \\
\text { becoming involved or being accomplices } \\
\text { in anticompetitive behavior }\end{array}$ & UN Global Compact, Principle 2 [32] \\
\hline & Promoting social responsibility $(\mathrm{Vc})$ & $\begin{array}{l}\text { Among suppliers, the presence of an } \\
\text { explicit code of conduct that protects the } \\
\text { human rights of workers }\end{array}$ & ISO:26000 [40] \\
\hline \multirow[t]{4}{*}{$\begin{array}{l}\text { Socioeconomic } \\
\text { repercussions }\end{array}$} & Access to material resources (Lc) & $\begin{array}{l}\text { Number of programs that aim to create } \\
\text { infrastructure for the mutual benefit of } \\
\text { the organization and the community }\end{array}$ & UN Global Compact, Principle 2 [32] \\
\hline & Access to immaterial resources $(\mathrm{Lc})$ & $\begin{array}{l}\text { Number of education programs for the } \\
\text { community }\end{array}$ & ISO:26000 [40] \\
\hline & Local employment (Lc) & $\begin{array}{l}\text { Percentage of workers belonging to local } \\
\text { communities }\end{array}$ & LFT [39] \\
\hline & Social acceptance (Lc) & $\begin{array}{l}\text { Percentage of respondents who consider } \\
\text { the existence of ranches to be positive for } \\
\text { the community }\end{array}$ & $\begin{array}{l}\text { IFC Performance Standard } 4 \text { [41] } \\
\text { UN Global Compact, Principle } 1 \text { [32] }\end{array}$ \\
\hline
\end{tabular}

$\mathrm{W}=$ Workers, $\mathrm{S}=$ Society, $\mathrm{Lc}=$ Local community, $\mathrm{Vc}=$ Value chain actors. 


\subsection{Sensitivity Analysis}

The sensitivity analysis consisted of evaluating four ranches belonging to educational institutions, called institutional ranches, in which management practices are carried out in accordance with the law. These ranches were used as "controls" and were intended to serve as guides for other ranches in the region. These ranches allowed us to analyze the relationship between social performance and formal management.

The Kruskal-Wallis $\mathrm{H}$ test $(p<0.05)$ was used to identify whether there was a difference between institutional and private (noninstitutional) ranches based on performance values (ranging from 1 to 4 ). Additionally, multivariate hierarchical clustering was used to analyze whether it was possible to obtain clusters of the ranches studied. For hierarchical cluster analysis (HCA), first, the optimum number of clusters that should be used in the classification was obtained through a stability function. Subsequently, the variables that are significant for each grouping, that is, those that are statistically significant for determining each of the clusters, were identified. Finally, analysis of the $p$-values for the hierarchical clusters via resampling by multiscale bootstrapping (also known as "pvclust") was performed to determine whether the groups formed by hierarchical clustering are statistically significant under a hypothesis test based on resampling [46].

HCA was based on the inventory data, the Euclidean distance was adopted as the dissimilarity measurement, and averaging was employed when defining the clusters. The analyses were performed using R statistical software [47].

In this study, the sensitivity analysis also considered a statistical analysis to determine whether there are statistically significant differences in the social performance of the 12 selected private ranches. Since the performance results are given in whole numbers between 1 and 4 (discrete numerical variables of ordinal type), the nonparametric Kruskal-Wallis $\mathrm{H}$ test was used.

Another analysis developed was the calculation of a global social performance index, which, from the assignment of weights, seeks to identify whether there are significant differences between private ranches. The calculation associates all the indicators established in Table 2 with the indicator "contribution to local employment", which is considered strategic in the social performance of the ranches because it contributes to local economic development. This indicator was obtained from the number of employees at each ranch and from the number of people employed in the local community [48]. Based on these data, the percentage of contribution to local employment was estimated for each system (MC, ISP, and NSP) analyzed. The percentage contribution of each system represents a weight by which each of the evaluated indicators was multiplied (see supplementary Table S4). The sum of the products generated the global performance index per system.

Table 2. Description of the social performance scale.

\begin{tabular}{|c|c|c|c|}
\hline Level & Scale & Social Performance & Rating Criteria \\
\hline & 4 & Outstanding & Proactive behavior in relation to the reference value \\
\hline & 3 & Acceptable & Meets the reference value \\
\hline & 2 & Poor & Does not meet the reference value \\
\hline & 1 & Very poor & $\begin{array}{l}\text { Does not meet the reference value and operation of the } \\
\text { organization in an unfavorable context (i.e., physical, } \\
\text { psychological, or security risks, or in violation of } \\
\text { human rights) }\end{array}$ \\
\hline & 0 & No data & No reported data \\
\hline
\end{tabular}




\section{Results and Discussion}

\subsection{Social Impact Assessment by State}

Table 3 shows the data inventory and social performance of the 12 private ranches in five out of 18 subcategories of impact analyzed Data inventory of all impact subcategories is available as supplementary material (see supplementary Table S6). Figure 2 illustrates the average performance score of the ranches for each production system and state (V and $\mathrm{Y}$ ). This figure shows that in $\mathrm{V}$, all systems have the same social performance level (1.89). In Y, the MC system is best (2.03), while the ISP system is the worst (1.98). Comparing the three livestock production systems between states, we find that those in $\mathrm{Y}$ have a better score. On the other hand, the average performance of ranches by stakeholders showed that workers have the lowest performance level (1.73) compared to the stakeholders in the local community (2.31), society (2.00), and the value chain (2.00).

As shown in Figure 2, ranches located in the state of $Y$ had better social performance than those located in $\mathrm{V}$, which can be attributed to the social and socioeconomic conditions of each of the study sites. $\mathrm{V}$ has a GDP of 2.3, while Y has a GDP of 3.2. Another determinant of this result could be the Human Development Index (HDI), which combines life expectancy at birth, education, and GDP per capita; this value is higher for $\mathrm{Y}$, having a value of 0.82 , than for $\mathrm{V}$, having a value of 0.78 (see supplementary Table S3). This result could indicate that, at a general level, the positive social impacts of livestock systems are higher when they are found in better social, socioeconomic, and geographic contexts.

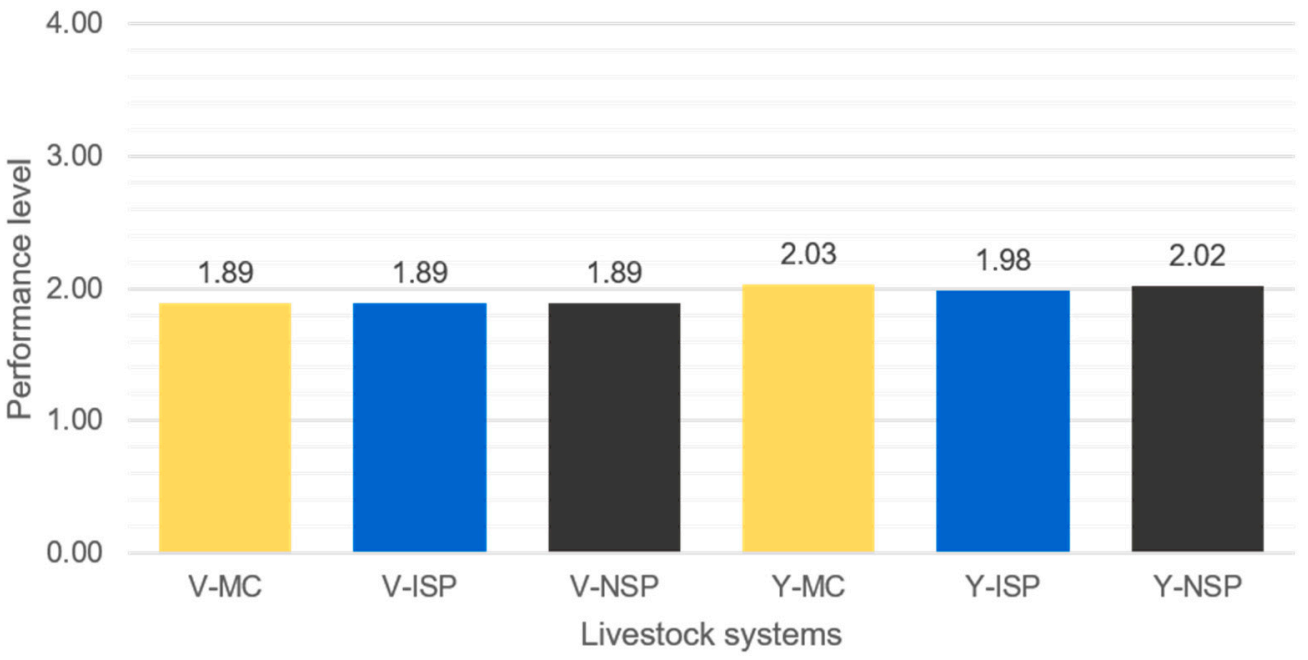

Figure 2. Comparative results of the average performance of livestock systems by state. V = Veracruz, $\mathrm{Y}=$ Yucatan, $\mathrm{MC}=$ monoculture; ISP = intensive silvopastoral; NSP = native silvopastoral. Performance level: $0=$ no data, $1=$ very poor, $2=$ poor, $3=$ acceptable, and $4=$ outstanding. 
Table 3. Data inventory by indicator for each of the cases studied for five impact subcategories.

\begin{tabular}{|c|c|c|c|c|c|c|c|c|c|c|c|c|}
\hline Subcategory/Inventory Indicator & VMC1 & YMC2 & YMC3 & VISP1 & YISP2 & YISP3 & YISP4 & VNSP1 & VNSP2 & YNSP3 & YNSP4 & YNSP5 \\
\hline \multicolumn{13}{|c|}{ Freedom of association and collective bargaining (W) } \\
\hline $\begin{array}{l}\text { Percentage of workers who are } \\
\text { members of a labor union }\end{array}$ & $0.00(1)$ & $0.00(1)$ & $0.00(1)$ & $0.00(1)$ & $0.00(1)$ & $0.00(1)$ & $0.00(1)$ & $0.00(1)$ & $0.00(1)$ & $0.00(1)$ & $0.00(1)$ & $0.00(1)$ \\
\hline \multicolumn{13}{|c|}{ Child labor (W) } \\
\hline Number of people under 15 working & $1.00(2)$ & $0.00(3)$ & $0.00(3)$ & $0.00(3)$ & $0.00(3)$ & $0.00(3)$ & $0.00(3)$ & $0.00(3)$ & $0.00(3)$ & $0.00(3)$ & $2.00(1)$ & $0.00(3)$ \\
\hline \multicolumn{13}{|c|}{ Fair salary $(W)$} \\
\hline $\begin{array}{l}\text { Average household income per capita } \\
\text { from the income of the worker }\end{array}$ & $1.25(1)$ & $2.50(2)$ & $1.59(1)$ & $1.97(1)$ & $1.74(1)$ & $1.66(1)$ & $1.51(1)$ & $1.89(1)$ & $1.00(1)$ & $2.13(1)$ & $0.95(1)$ & $0.94(1)$ \\
\hline \multicolumn{13}{|c|}{ Working hours (W) } \\
\hline $\begin{array}{l}\text { Average number of hours } \\
\text { worked/week }\end{array}$ & $63(1)$ & $64(1)$ & $44(3)$ & $52(2)$ & $63(1)$ & $36(1)$ & $48(3)$ & $49(2)$ & $40(1)$ & $57(2)$ & $31.50(1)$ & $35(1)$ \\
\hline \multicolumn{13}{|c|}{ Forced labor (W) } \\
\hline $\begin{array}{l}\text { Number of hours of forced labor } \\
\text { identified during the study period }\end{array}$ & $0.00(3)$ & $0.00(3)$ & $0.00(3)$ & $0.00(3)$ & $0.00(3)$ & $0.00(3)$ & $0.00(3)$ & $0.00(3)$ & $0.00(3)$ & $0.00(3)$ & $0.00(3)$ & $0.00(3)$ \\
\hline
\end{tabular}




\subsection{Analysis by Impact Category}

\subsubsection{Human Rights}

The comparison of the average normalized values of the subcategories included in the human rights category ("child labor", "equal opportunities and discrimination", and "freedom of association and collective bargaining") among the ranches evaluated showed that all ranches have a very poor performance level (1 in Table 3) (Figure 3).

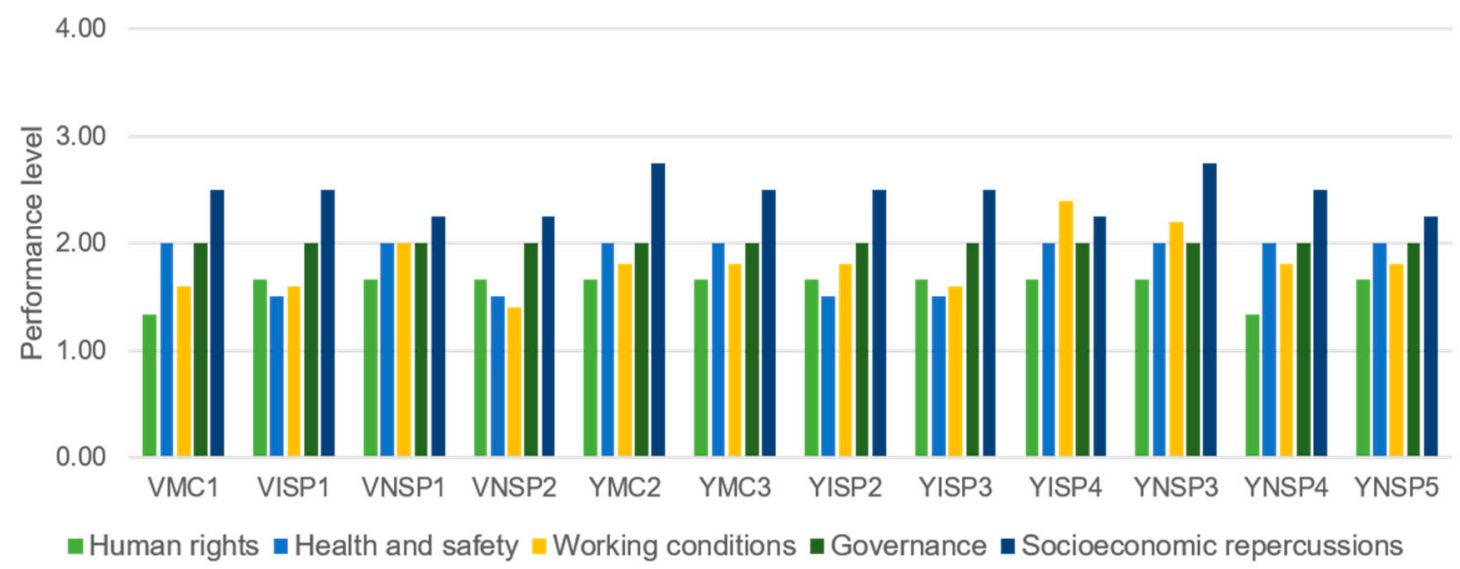

Figure 3. Comparison of the social performance of noninstitutional ranches by impact category. Performance level: $0=$ no data, $1=$ very poor, $2=$ poor, $3=$ acceptable, and $4=$ outstanding.

\section{Child Labor}

The law forbids the employment of children under 15 years of age, and those over this age can provide their services within the limitations established by law [31,39]. In the current study, child labor was identified at two ranches during the period evaluated; the working children were the children of the farm owners. The law indicates that child labor will be allowed only in productive family activities for self-consumption [39], which does not apply in this case because the production is also intended for sale; therefore, these ranches are violating the law.

Child labor was identified in VMC1, where the owner requires his son, under 15, to work at the ranch because the owner considers that, in this way, his son will grow as a man. At YNSP4, the two children of the owner work during their school vacation periods; they are 6 and 12 years old. The participation of children in some types of work, such as helping at home or in a family business, can be beneficial for personal training since it gives children the possibility of acquiring skills for adulthood [49]; however, activities in the field represent a physical risk for children. Although there were no reported work-related accidents involving children in the period studied, we believe that child labor should not be allowed since more than $21 \%$ of accidents in field activities involve children and practically all accidents in field activities involve family members [50].

\section{Freedom of Association and Collective Bargaining}

The International Labor Organization (ILO) [36] states that "Workers and employers have the right to establish and, subject only to the statutes of the corresponding organization, to join organizations of their own choosing without prior authorization". In this study, restrictions on workers' freedom of association were not found; however, at none of the ranches were workers associated with a labor union, which may be due to ignorance of their rights, as noted in the interviews. The lack of workers' associations is a common characteristic of rural employment in Latin American regions, and it strongly limits the protection of workers' rights [51], facilitating the existence of precarious working conditions that, in turn, cause discontent and social dissatisfaction that can lead to the abandonment of the countryside. 


\section{Equal Opportunities and Discrimination}

In the present analysis, no incidents of discrimination by employers or workers were identified; however, none of the ranches met the RV for this subcategory because the participation of women in the work of the ranches was almost nil and only one working woman was identified at one of the ranches (YNSP4). The low participation of women in agricultural work is understandable because the work is hard and those responsible prefer to hire male labor, as was mentioned by some of the ranch owners. This result is similar to that found by Chen and Holden [21] in Irish dairy farms, where labor is also dominated by men. Brandth [52] considers that this phenomenon may be related to family structures and property; at the ranches, there is discrimination by employers against women since employers prefer to hire men due to their greater capacity to put forth physical effort, which reduces the chances for women to work and become independent.

The results identified the low participation of rural women in wage labor as an example of the few opportunities that exist for women's development and as an example of women's economic dependence on men. In Latin America, the cultural assignment of differentiated social roles, where men are providers and women are responsible for reproduction, the childrearing, and housework, has caused the late incorporation of women into work. This concept is the basis of much discrimination against women, especially in rural areas [53]. These issues emphasize the need to close the gender gap to include rural women in wage labor, which is contained in the fifth Sustainable Development Goal concerning gender equality [54].

\subsubsection{Health and Safety}

The "health and safety" category was evaluated through the subcategories "health and safety" and "safe and healthy living conditions". To assess the "health and safety" subcategory, two inventory indicators were used: the "number of work accidents" and "presence of a formal policy concerning health and safety". Although only four of the 12 noninstitutional ranches reported work accidents during the study period, none had an acceptable level of social performance in this subcategory since all of them lacked a formal policy for health and safety according to the standards established in by law [39].

The agricultural sector is considered one of the three most dangerous sectors in the world $[33,55]$; therefore, the existence of a formal policy concerning health and safety in organizations is a requirement established by law. It is necessary for livestock organizations to meet legal requirements to prevent accidents at work since they can result in serious injuries [56] with negative effects on family income by reducing the employee's physical capacity to work or through job dismissal. It is necessary to establish monitoring plans regarding health and safety that rely on external representatives who are not ranch workers and who visit the ranches to monitor legal compliance.

The main impact on human health generated by livestock is direct; that is, it is on the workers. In this regard, no complaints were identified by the community; however, in the "healthy living conditions" subcategory, the ranches obtained poor social performance scores (performance level = 2) because they do not include programs that contribute to the prevention of diseases in the community.

\subsubsection{Working Conditions}

The "working conditions" category included the subcategories "fair salary", "working hours", "forced labor", "social benefits/social security", and "job satisfaction". Figure 3 shows that three ranches had a poor performance level and that nine had a very poor level. This result differs from that obtained by Chen and Holden [21], who obtained favorable results in most of the indicators for worker stakeholders. 
Fair Salary

According to the inventory data (Table 3), the workers with the highest per capita income and the only workers who are above the income poverty line are from ranch YMC2. Those with the lowest income work at ranch YNSP5 (2.50 vs. $0.94 \mathrm{USD} / \mathrm{d}$ ). That is, in $92 \%$ of the ranches, the workers have an income that places them in a situation of extreme poverty. This result is in line with the findings reported by Hurst [55]. Some of the characteristics of the payment of salaries include the lack of payment of overtime at all the ranches and payment in kind with the milk produced; these practices violate labor rights [39].

\section{Working Hours}

In the "working hours" subcategory, only two ranches (YMC3 and YISP4) met the RV (performance level 3 in Table 3), three ranches (VNSP1, VISP1, and YNSP3) has poor performance (2 in Table 3), and the remaining ranches had very poor performance (1 in Table 3$)$.

Four ranches (VNSP2, YISP3, YNSP4, and YNSP5) had a very poor performance level (1 in Table 3) because they presented conditions of underemployment (under $42 \mathrm{~h}$ per week). Underemployment is frequently observed in the agricultural sector and is an important cause of poverty for workers in this sector [57].

The average number of working hours per week per worker in the evaluated ranches is in the range of 32 to 63 , but we found that at a ranch, employees can work up to $84.5 \mathrm{~h}$ per week (Table 3). The excess number of working hours identified in this study coincides with other activities of the agricultural sector in Latin America, as reported by Franze and Ciroth [51] in regard to the production of roses in Ecuador. This study observed that the distribution of workers by weekly working hours is as follows: only $28 \%$ work the number of hours established by law, $24 \%$ work between 48 and $57 \mathrm{~h}$, another $24 \%$ are underemployed, and the remaining $24 \%$ work more than $57 \mathrm{~h}$; that is, $72 \%$ of workers are in precarious conditions of work in relation to the "working hours" subcategory. The workers did not mention conflicts at work and expressed a good relationship with their employers; however, a general disagreement about work schedules was identified. The number of working hours is recognized as a fundamental factor in the well-being of workers and their families; therefore, it is important to have effective monitoring of legal compliance regarding this issue. The ideal is to achieve the full employment of people, with workers achieving high productivity and being able to develop their skills [58] without affecting their well-being and that of their families. Achieving this ideal would contribute to achieving Sustainable Development Goal 8 (decent work and economic growth) [54].

\section{Forced Labor}

In the interviews with the workers, forced labor was not identified; thus, the performance of the ranches with respect to this subcategory was acceptable ( 3 in Table 3). This result coincides with that reported by Franze and Ciroth [51] in an SLCA carried out in Ecuador, a country in which the conditions of production in the field are similar to those prevalent in Mexico.

However, the working conditions present at some ranches (VMC1 and YISP2) showed violations of both legal and human rights, e.g., prolonged working hours without overtime payment and a lack of provision of, or the conditioning of, days off. Although the aforementioned practices do not coincide with the ILO definition of forced labor, they show clear features of abuse and the inhumane treatment of workers.

\section{Social Benefits/Social Security}

In this subcategory, $100 \%$ of the ranches fail to meet the RV. The lack of social benefits in employment is common in rural areas in developing countries [57], which coincides with the report of Franze and Ciroth [51] but contradicts the report of Chen and Holden [21] regarding Ireland and 
the Netherlands, where social benefits are granted. Therefore, the intervention of national agencies is important to ensure compliance with national and international laws in this regard.

Although workers in the livestock sector are formally categorized under the national law [39] as "field workers" with specific rights, this group of workers is truly unprotected since the laws and regulations regarding social benefits do not apply in the ranches analyzed because at these ranches, work is performed under informal conditions. The benefits granted to the workers at the evaluated ranches are as follows: $77 \%$ receive a Christmas bonus; $52 \%$ receive days off; $44 \%$ receive vacation, but the number of days granted is less than what is established by law; and $12 \%$ receive social security.

Regarding worker training, only two ranches, YMC2 and YNSP5, provide this benefit. Therefore, the possibility that a worker can gain access to a better salary as a skilled laborer does not exist, which confirms that rural poverty is related to unskilled labor, a common characteristic of work in the Mexican countryside [57]. Through the interviews, it was identified that some workers have trained on their own initiative because they want to access jobs with better incomes and know that training is a tool for job growth.

Working conditions must be recorded in written contracts [39]; however, in this SLCA, none of the private ranches analyzed met the RV. In Mexico, there are usually few written contracts in the agricultural sector; verbal agreements prevail, but they leave workers, who do not know their rights and do not have an organization to support them, at a clear disadvantage [57].

Job Satisfaction

Job satisfaction is understood as "the feeling of well-being derived from working conditions, the performance of tasks, belonging to an organization and achieving professional goals and achievements" [59], which is considered to be closely linked to company productivity; therefore, a lower intention to change jobs shows greater job satisfaction [60]. To determine job satisfaction, workers were asked about their desire to change jobs. Forty-six percent answered that they would change jobs, motivated by better working conditions and better remuneration. The results of the evaluation show that only five ranches met the RV, two ranches had a poor performance level, and five ranches had very poor performance. Job satisfaction increases commitment and loyalty to an organization; therefore, there is a low desire to change jobs, which was not found in the context of the livestock ranches evaluated [61].

\subsubsection{Governance}

The four impact subcategories included in the category "governance" ("community engagement", "public commitments to sustainability issues", "fair competition", and "promoting social responsibility") reached a performance level equal to 2, equivalent to a poor rating (Figure 3).

\section{Community Engagement}

An important feature of organizations in the community is recognizing and taking into account the interests and legal rights of their stakeholders and responding to expressions of their concerns, in addition to evaluating and taking into account the relative capacity of stakeholders to contact, participate in, and influence the organization [40,41]. Due to the lack of formal mechanisms for including the opinion of the community in the decisions made by the ranches, the 12 private ranches analyzed had a poor performance level (equivalent to 2) in this subcategory (Figure 3).

\section{Public Commitments to Sustainability Issues}

In this subcategory, all the ranches had poor performance (equivalent to 2) because they lack agreements and/or reports regarding their environmental, social, and economic performance. In Mexico, it is difficult for this type of practice to be carried out in livestock organizations such as those that were evaluated since informality is a characteristic that prevails in these systems. 
Fair Competition and Promotion of Social Responsibility

Both "fair competition" and "promotion of social responsibility" are subcategories associated with value chain actors. Additionally, they are framed in principle 2 of the UN Global Compact [32], which stipulates that companies must ensure that they are not accomplices in the violation of the human rights of interested parties, either by an act or by omission, which occurs more often in areas with weak governance. In relation to "fair competition", the ranches do not have policies or strategies to avoid the involvement of the company in anticompetitive practices. Furthermore, among the suppliers of the ranches or the buyers of their products, there is no explicit code of conduct that protects the human rights of workers. Therefore, the livestock ranches analyzed in this study do not meet the RV.

\subsubsection{Socioeconomic Repercussions}

The social performance of the ranches in the "socioeconomic repercussions" category was poor (Figure 3). The subcategories evaluated in this impact category were "access to material resources", "access to immaterial resources", "local employment", and "social acceptance"; of these subcategories, only the "local employment" subcategory achieved a rating of 4 for all ranches, and the "social acceptance" subcategory met the RV at two ranches.

Access to Material Resources and Access to Immaterial Resources

The performance of the ranches in the subcategories "access to material resources" and "access to immaterial resources" was poor (performance level $=2$ ) because the ranches do not have programs, formal or informal, that aim to support education, create infrastructure, or improve the health of local communities. Participation in the improvement of the community both in infrastructure and in the development of residents is part of corporate social responsibility [40]. The decision of the organizations to positively contribute to the improvement of the local community is a voluntary decision that means an opportunity to support the protection of human rights in socially underdeveloped communities [32]. The owners of the ranches could improve their social performance by supporting improvements in the community.

\section{Social Acceptance}

The behavior of the ranches towards local communities is reflected in the "social acceptance" subcategory, which was evaluated by asking local residents whether they consider the existence of the ranches to be positive for the community. In this subcategory, only two ranches (16.6\%) meet the RV. It was identified that there is a perception that the owners of the ranches are concerned about only their own interests, that they cause deforestation and pollution and that the jobs they offer are scarce and poorly paid. However, some interviewees (VMC1, VISP1, VNSP1, and NSP2) considered that the existence of the ranches is favorable because they are a source of employment, promote agriculture, sometimes support traditional festivals, and sell locally produced food.

Local Employment

The generation of local employment by companies is considered a generator of economic development. In this study, the 12 ranches analyzed had an outstanding performance in the "local employment" subcategory because $100 \%$ of their employees belong to nearby communities. However, the jobs offered by the ranches are scarce; thus, the positive impact of this subcategory is low.

\subsection{Sensitivity Analysis}

\subsubsection{Institutional Ranches}

The results obtained from the sensitivity analysis for the institutional ranches showed that management is the most relevant variable that influences the social performance of ranches in the 
Mexican tropics since the institutional ranches presented better performance than the private ranches in four out of five impact categories evaluated (Figure 4). This result is in line with Siebert et al. [62], who state that the social implications are associated with the conduct of the organizations along the life cycle.

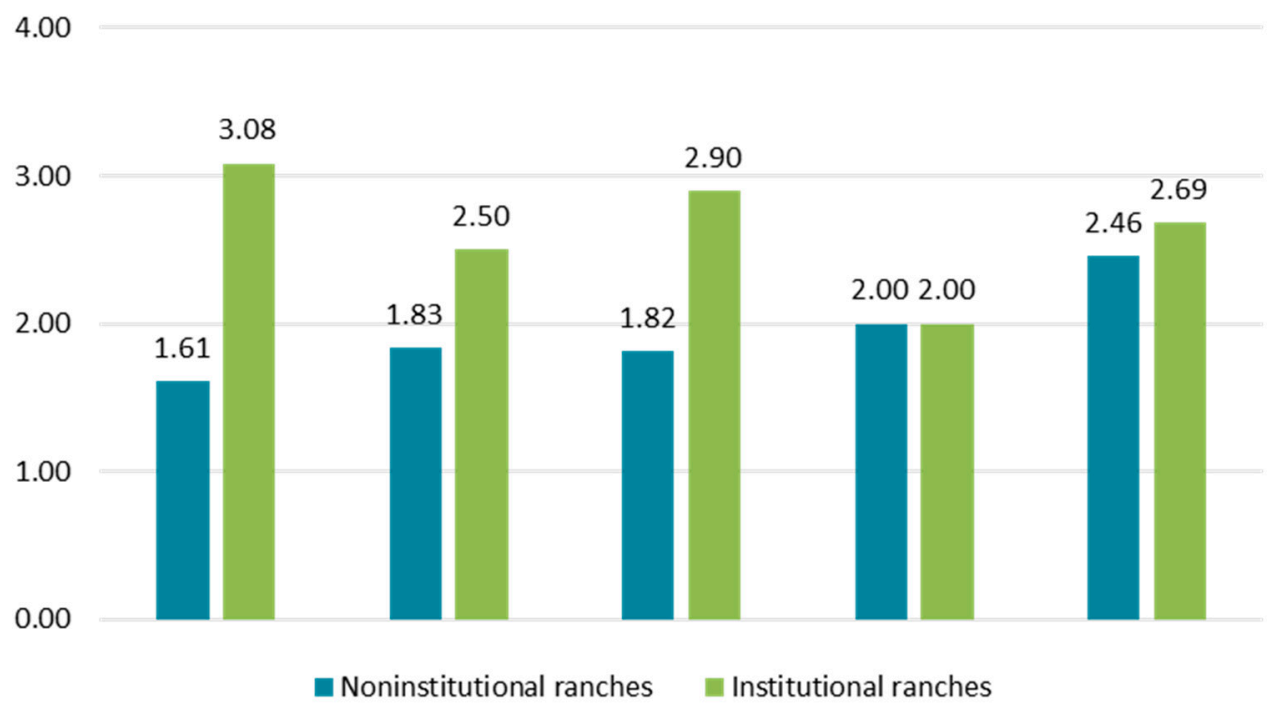

Figure 4. Comparison of the social performance of the institutional and noninstitutional ranches by impact category. Performance level: $0=$ no data, $1=$ very poor, $2=$ poor, $3=$ acceptable, and $4=$ outstanding.

However, the institutional ranches achieved acceptable performance only in the category "human rights". In the categories "health and safety", "working conditions", "governance", and "socioeconomic repercussions", they showed poor performance.

The best performance of the institutional ranches was in the "human rights" category since the workers are affiliated with a union and no child labor was identified during the evaluated period. However, in the "equal opportunities/discrimination" subcategory, no working women were identified in three of the institutional ranches; therefore, they had a very poor performance rating.

Regarding the "health and safety" category, all institutional ranches met the RV; however, in the "safe and healthy living conditions" subcategory, their performance was poor. In the "working conditions" impact category, the institutional ranches met the RV of the "forced labor", "social benefits/social security", and "job satisfaction" subcategories; however, in the "fair salary" category, none of the ranches met the RV, and in the "working hours" category, only two ranches met the RV.

In the "fair salary" subcategory, none of the institutional ranches met the RV. The ranches comply with paying workers the minimum wage established by law; however, this salary is not above the poverty line established in this study as a RV. Educational institutions are obliged to pay only the current minimum wage established by law, a salary that does not guarantee that workers and their families can cover their basic needs. However, the institutional ranches in this subcategory have a higher average performance value than do the noninstitutional ranches (1.5 vs. 1.1).

In the "working hours" subcategory, during the evaluated period, two of the institutional ranches (I-VMC1 and I-VMC2) had very poor performance because of the existence of underemployment due to few working hours.

In the "socioeconomic repercussions" category, the institutional ranches did not reach an acceptable performance level because only two out of four impact subcategories ("access to immaterial resources" and "local employment") met the RV.

The dendrogram obtained by the HCA using the pvclust package (95\%) (cluster analysis) shows the agglomeration of the 16 ranches in three groups (Figure 5). This grouping has a probability greater than $95 \%$, as indicated by the AU $p$-values in the dendrogram. Cluster A groups the four institutional 
ranches; Cluster B includes five ranches, two with the ISP system, and three with the NSP system; and Cluster $C$ includes the seven remaining ranches: three ranches with the MC system, three with the ISP system, and one with the NSP system (all noninstitutional). According to the cutreevar function of the "ClustOfVar" method, an R package for the clustering of variables, the similarity variables of Cluster A are the "labor benefits" and "fair salary" subcategories, as these ranches had the best performance value in these subcategories; in Cluster B, the similarity variables are "working hours" and "social acceptance"; and in Cluster C, the similarity feature is "job satisfaction".

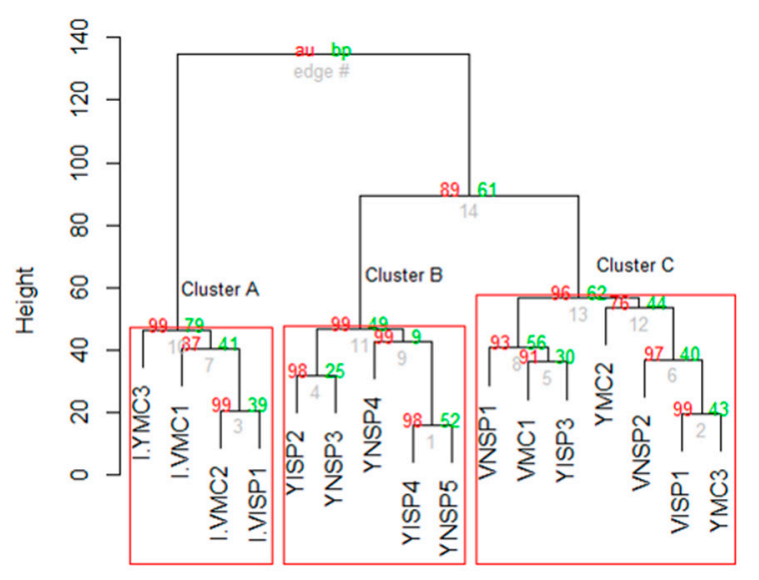

Distance: euclidean

Cluster method: average

Figure 5. Hierarchical clustering tree of the 16 ranches (institutional (I) and noninstitutional). The vertical axis represents the distance in similarity between ranches. Values at branches are AU $p$-values (left), BP values (right), and cluster labels (bottom).

The reason for the best performance of the institutional ranches with respect to noninstitutional reaches is that these ranches are obliged by a labor contract to comply with the law, especially with regard to the workers.

In accordance with the above results, diverse socioeconomic conditions act on workers in a way that favors abuse by employers, including the lack of legal orientation, the lack of education and the ignorance of their labor rights, such that they do not find effective ways to negotiate better labor and salary conditions, which is in line with the findings reported by Contreras [56]. This phenomenon is exacerbated by socioeconomic situations of poverty that lead to the acceptance of unfavorable and unfair working conditions [63].

One relevant factor that makes possible the poor social performance of the livestock production systems studied is the lack of vigilance in compliance with legal frameworks regarding social matters, which is why establishing adequate monitoring instruments is necessary. Doing so will mean the development of local norms that cover the particular requirements of the economic activities of the field and the creation of a monitoring agency (governmental or civil) that supervises and receives complaints concerning noncompliance with laws regarding social matters and that has the abilities to intervene to rectify violations by the ranches. The above will support improving the working conditions of workers and, in general, improve the welfare of all stakeholders in livestock systems.

Additionally, it would be appropriate to implement social agriculture programs to increase the empowerment of women, provide social assistance to children, and promote the recovery of the dignity of the rural worker, practices that are widespread in Europe and that should be applied in developing countries such as Mexico.

The sensitivity analysis shows that even when institutional ranches comply with legal requirements, they do not achieve acceptable social performance because the RVs for evaluating the impact subcategories established in this study were based not only on compliance with legal requirements but 
also on human rights. Therefore, it is necessary to reformulate the laws regarding social matters by considering the basic well-being requirements of people based on local social and cultural situations.

Establishing local standards will support obtaining more accurate results through the use of SLCA, achieving better coverage when evaluating social impacts. Such results will reflect the points of opportunity to raise the quality of life of stakeholders and thus promote human dignity and well-being.

\subsubsection{Private Ranches}

The results of the Kruskal-Wallis H test showed that there is no significant difference $(p>0.05)$ in the social performance of the 12 noninstitutional or private ranches.

The results of the global performance index calculated from the contribution to local employment did not allow us to distinguish significant differences in social aspects between the systems analyzed. However, the results of this analysis are considered "inconclusive" since it is not unlikely that there would be an important impact (the 95\% confidence interval across the threshold for what is considered to be an important effect). The social performance scores were $0.30,0.35$, and 0.35 for the MC, ISP, and NSP systems, respectively (see supplementary Tables S4 and S5). The reason may be that the social performance of livestock activities is the result of a complex interaction of the social, economic, and political factors involved in the region. Thus, the results for the livestock systems evaluated can mainly be explained by their social context and not by the type of agricultural production system.

Regarding the social context, southeastern Mexico is the region with the lowest economic development in the country, with an average annual growth in GDP of $1.3 \%$ (56\% less than the rest of the country, which is above 3\%) [64]. Furthermore, this region has the largest national indigenous population (56.26\%) [65], which is considered a vulnerable group due to conditions of social marginalization (e.g., high levels of illiteracy, lack of access to social security, and lack of access to food) [66] (In addition, lower levels of education in the employed population are present in this region [57]. This context leads farmers to provide unfavorable working conditions and precarious salaries to their employees and to show indifference to or little interest in contributing to improving local social well-being. Our results are in line with those of Dumont and Baret [67], who note that the socioeconomic and political context, history, work orientation, and sociocultural heritage exert a greater influence on producers' working conditions than does their degree of mechanization.

At the same time, the agricultural sector has conditions of economic lag compared to other sectors. Its participation in the generation of jobs is the lowest, and it contributes only $11 \%$ of the employed population, while the services, secondary, and commercial sectors show percentages of employment of $44 \%, 25 \%$, and $18 \%$, respectively [57]. Additionally, the labor markets, particularly the agricultural markets, tend to be informal $[64,68]$, which favors legal noncompliance.

From the perspective of the sustainability of the sector, the above results are worrisome since the informality of these producers (most of them are small) prevents them from accessing financing programs for the acquisition of technological tools, infrastructure, or specialized advice, perpetuating low economic growth. In addition, the precarious working conditions of the agricultural sector have caused the abandonment of agriculture and have increased nonagricultural rural work (e.g., small shops and transport services), leading to, among other things, the transformation of societies in rural areas and the loss of their cultural identity [69].

\section{Conclusions and Recommendations}

The results shown in this work can contribute to both the livestock and SLCA fields because the data provided present real case studies that move towards a full SLCA. Although this work is not a full SLCA, it can be considered an innovative social sustainability evaluation, and therefore, it can be considered a tool for achieving the sustainable development of livestock production.

The scoring approach methodology with a life cycle perspective allowed us to objectively evaluate the social performance of ranches using three tropical livestock systems in Mexico. Based on the results, in the social context, the ISP system does not have a better social impact than the MC and NSP systems. 
The average value of performance of the noninstitutional or private ranches with the MC system was better in the impact subcategories "health and safety", "social benefits", and "social acceptance"; the ranches with the ISP system had better performance in "child labor"; and those with the NSP system had better performance in the subcategory "equal opportunities/discrimination". Nonetheless, all these ranches had poor performance.

The results showed that there is no relationship between social performance and the production system. Rather, it depends on the management practices of each ranch and on complex socioeconomic processes. We suggest that the behavior of livestock ranches is a reflection of the social, economic, and cultural realities in the study sites. With more research and more documentation drawing from practice, where the uncertainty in SCLA mostly comes from will become clearer. For the moment, one idea would be to qualitatively document uncertainty at the unit process level and according to which type of data collection is used and how the data are aggregated. Additionally, a stochastic analysis should be implemented to explore the entire feasible weight space using probabilistic weights.

The results obtained in this SLCA have high precision since the data used were obtained at the farm level, that is, at the local level, and were specific to the livestock sector. In this study, rigorous RVs were used to rate the performance of the ranches; therefore, because rural economic activities in Mexico are usually informal, it is understandable that the social performance levels of the ranches were poor. However, the completeness and rigor of the methodology used allowed us to understand the reality of the performance of ranches in southeastern Mexico.

This study showed unfavorable results for a sector with a strategic function to reduce rural poverty and ensure food security in Mexico; therefore, in conclusion, the livestock ranches evaluated are not sustainable from the social perspective. To improve the social impacts of livestock ranching, institutional involvement in monitoring legal compliance and in developing and implementing strategies that support the transition to sustainable livestock systems is essential. A coordinated effort that addresses a wide variety of economic, social, cultural, and legal problems is required to prevent abuse of workers, to reduce their vulnerability, and to generate greater positive social impacts. Within the possibilities for improving this sector that exist, labor inspection is essential to guarantee that labor legislation is applied. The participation of ranches in improving the well-being of local communities and in including their opinions and concerns in decision making within the ranches is also essential. Additionally, it is necessary to reformulate laws regarding social matters by considering the basic well-being requirements of people based on local social and cultural situations.

To have a complete SLCA, future work should include consumer interest groups. Additionally, it is necessary to incorporate indicators that include cultural, social, and economic contexts and to analyze institutional performance and its impact on the livestock sector.

Finally, further research is needed, and there is room for improvement. This paper shows that there are limitations and challenges to developing SLCA in light of social sustainability. We identified four main challenges: those concerning generalization (this research is based on case studies, and therefore, the results cannot be applied for local or regional decision making), data uncertainty, extension of the indicators used, and the lack of measurement of positive impacts.

Supplementary Materials: The following are available online at http://www.mdpi.com/2071-1050/11/16/4419/s1, Table S1: Inventory indicators with reference values and evaluation criteria, Table S2: Characteristics of the ranches analyzed, total number of workers interviewed at each ranch, and local inhabitants surveyed, Table S3: Socioeconomic data of the sites where the ranches are located, Table S4: Score for the subcategories of impact and global social performance index at each ranch, Table S5: Weight associated with the contribution to local employment by livestock system, Table S6. Data inventory by indicator for each of the cases studied.

Author Contributions: Conceptualisation, L.P.G., A.R.-H., M.d.1.S.R.L. and A.P.-R.; methodology, L.P.G., A.R.-H. and A.P.-R.; data collection, A.R.-H. and A.P.-R.; data analysis, A.R.-H.; writing-original draft preparation, A.R.-H.; writing-review and editing, L.P.G., A.R.-H., A.P.R. and M.d.I.S.R.L.

Funding: This research was funded by by "Programa de Apoyo a Proyectos de Investigación e Innovación Tecnológica” grant number PAPIIT IV200715. 
Acknowledgments: The first author gratefully acknowledges the National Council of Science and Technology (CONACyT) for her Ph.D. scholarship and the Program in Sustainability Sciences, UNAM (Posgrado en Ciencias de la Sostenibilidad, Universidad Nacional Autónoma de México). We appreciate the valuable collaboration of Francisco A. Ruiz López in the data collection, María E. Villalba Pastrana for her support in the data collection and analysis, and Alejandro Frías Villegas for his support in the statistical analysis.

Conflicts of Interest: The authors declare no conflict of interest.

\section{References}

1. Steinfeld, H.; Gerber, P.; Wassenaar, T.; Castel, V.; Rosales, M.; de Haan, C. Livestock's Long Shadow: Environmental Issues and Options; Food and Agriculture Organization of the United Nations: Rome, Italy, 2006.

2. Herrero, M.; Thornton, P.K.; Gerber, P.; Reid, R.S. Livestock, livelihoods and the environment: Understanding the trade-offs. Curr. Opin. Environ. Sustain. 2009, 1, 111-120. [CrossRef]

3. Perry, B.; Sones, K. Poverty reduction through animal health. Science 2007, 315, 333-334. [CrossRef] [PubMed]

4. FAOSTAT. Food and Agriculture Data. Livestock primary. Rome: Statistics Division Food and Agriculture Organization of the United Nations. 2017. Available online: http://www.fao.org/faostat/en/\#home (accessed on 12 September 2018).

5. Rojo-Rubio, R.; Vázquez-Armijo, J.F.; Pérez-Hernández, P.; Mendoza-Martínez, G.D.; Salem, A.Z.M.; Albarrán-Portillo, B.; González-Reyna, A.; Hernández-Martínez, J.; Rebollar-Rebollar, S.; Cardoso-Jiménez, D.; et al. Dual purpose cattle production in Mexico. Trop. Anim. Health Prod. 2009, 41, 715-721. [CrossRef]

6. SIAP. Estadísticas de Producción ganadera para México. 2017. Available online: https://www.gob.mx/siap/ acciones-y-programas/produccion-pecuaria (accessed on 8 February 2019).

7. Ibrahim, M.; Guerra, L.; Casasola, F.; Neely, C. Importance of silvopastoral systems for mitigation of climate change and harnessing of environmental benefits. In Grassland Carbon Sequestration: Management, Policy and Economics; FAO Integrated Crop Management, FAO: Rome, Italy, 2010; Volume 11, pp. 189-196.

8. Pelletier, N.; Pirog, R.; Rasmussen, R. Comparative life cycle environmental impacts of three beef production strategies in the Upper Midwestern United States. J. Agric. Syst. 2010, 103, 380-389. [CrossRef]

9. Rivera-Huerta, A.; Güereca, L.P.; Rubio, M. Environmental impact of beef production in Mexico through life cycle assessment. Resour. Conserv. Recycl. 2016, 109, 44-53. [CrossRef]

10. Souza, D.M.; De Petre, R.; Jackson, F.; Hadarits, M.; Pogue, S.; Carlyle, C.N.; Bork, E.; Mcallister, T. Value Chain: State-of-the-Art and Recommendations for Future Improvements. Animals 2017, 7, 26. [CrossRef] [PubMed]

11. Willers, C.D.; Maranduba, H.L.; Neto, J.A.; Rodrigues, L.B. Environmental Impact assessment of a semi-intensive beef cattle production in Brazil's Northeast. Int. J. Life Cycle Assess. 2017, 22, 516-524. [CrossRef]

12. Zhuang, M.; Gongbuzeren, L.W. Greenhouse gas emission of pastoralism is lower than combined extensive/intensive livestock husbandry: A case study on the Qinghai-Tibet Plateau of China. J. Clean. Prod. 2017, 147, 514-522. [CrossRef]

13. De Freitas, D.S.; de Oliveira, T.E.; de Oliveira, J.M. Sustainability in the Brazilian pampa biome: A composite index to integrate beef production, social equity, and ecosystem conservation. Ecol. Indic. 2019, 98, 317-326. [CrossRef]

14. Riethmuller, P. The social impact of livestock: A developing country perspective. Anim. Sci. J. 2003, 74, 245-253. [CrossRef]

15. Angelsen, A.; Kaimowitz, D. (Eds.) Agricultural Technologies and Tropical Deforestation; CABI Publishing: Wallingford, UK, 2001.

16. Chhipi-Shrestha, G.K.; Hewage, K.; Sadiq, R. "Socializing" sustainability: A critical review on current development status of social life cycle impact assessment method. Clean Technol. Environ. Policy 2015, 17, 579-596. [CrossRef]

17. UNEP/SETAC. Guidelines for Social Life Cycle Assessment of Products; UNEP/SETAC Life Cycle Initiative: Paris, France, 2009.

18. ISO. ISO 14040_Environmental Management_Life Cycle Assessment_Goal and Scope_Principles and Framework; International Organization for Standardizatio: Geneva, Switzerland, 2006.

19. ISO. ISO 14044_Environmental Management_Life Cycle Assessment_Requirements and Guidelines; International Organization for Standardization: Geneva, Switzerland, 2006. 
20. Revéret, J.-P.; Couture, J.-M.; Parent, J. Socioeconomic LCA of Milk Production in Canada; Social Life Cycle Assessment. An Insight; Muthu, S., Ed.; Springer: Singapore, 2015; pp. 25-69. [CrossRef]

21. Chen, W.; Holden, N.M. Social life cycle assessment of average Irish dairy farm. Int. J. Life Cycle Assess. 2017, 22, 1459-1472. [CrossRef]

22. Petti, L.; Serreli, M.; Di Cesare, S. Systematic literature review in social life cycle assessment. Int. J. Life Cycle Assess. 2018, 23, 422-431. [CrossRef]

23. Arcese, G.; Lucchetti, M.; Merli, R. Social Life Cycle Assessment as a Management Tool: Methodology for Application in Tourism. Sustainability 2013, 5, 3275-3287. [CrossRef]

24. Falcone, P.; Imbert, E. Social Life Cycle Approach as a Tool for Promoting the Market Uptake of Bio-Based Products from a Consumer Perspective. Sustainability 2018, 10, 1031. [CrossRef]

25. Takeda, S.; Keeley, A.; Sakurai, S.; Managi, S.; Norris, C. Are Renewables as Friendly to Humans as to the Environment?: A Social Life Cycle Assessment of Renewable Electricity. Sustainability 2019, 11, 1370. [CrossRef]

26. Dreyer, L.; Hauschild, M.; Schierbeck, J. A Framework for Social Life Cycle Impact Assessment. Int. J. Life Cycle Assess. 2006, 11, 88-97. [CrossRef]

27. Ruviaro, C.; de Léis, C.; Lampert, V.; Jardim, B.; Dewes, H. Carbon footprint in different beef production systems on a southern Brazilian farm: A case study. J. Clean. Prod. 2015, 96, 235-443. [CrossRef]

28. Ellis, E.; Hernández-Gómez, I.; Romero-Montero, J. Los procesos y causas del cambio en la cobertura forestal de la Península Yucatán, México. Ecosistemas 2017, 26, 101-111. [CrossRef]

29. Padilla-Rivera, A.; Morgan-Sagastume, J.M.; Noyola, A.; Güereca, L.P. Addressing social aspects associated with wastewater treatment facilities. Environ. Impact Assess. Rev. 2016, 57, 101-113. [CrossRef]

30. Yildiz, G.; Altun, Ç.; Neşet, K. Social life cycle assessment of different packaging waste collection system. Resour. Conserv. Recycl. 2017, 124, 1-12. [CrossRef]

31. ILO. International Labor Organization Convention, No: 138. 1973. Available online: https://www.ilo.org/ dyn/normlex/en/f?p=NORMLEXPUB:12100:0::NO::P12100_ILO_CODE:C138 (accessed on 15 August 2018).

32. UN. Global Compact. The Power of Principles. 2017. Available online: https://www.unglobalcompact.org/ what-is-gc/mission/principles/principle-2 (accessed on 25 August 2018).

33. ILO. Safety and Health in Agriculture Convention, No. 184. 2001. Available online: https://www.ilo.org/dyn/ normlex/en/f?p=NORMLEXPUB:12100:0::NO::P12100_ILO_CODE:C184 (accessed on 1 September 2018).

34. CEDAW. Convention on the Elimination of All Forms of Discrimination against Women. UN: New York, NY, USA, 18 December 1979. Available online: http://www.un.org/womenwatch/daw/cedaw/cedaw.htm (accessed on 15 January 2019).

35. ILO. Convention concerning the Rights of Association and Combination of Agricultural Workers (No. 11). 1921. Available online: https://www.ilo.org/dyn/normlex/en/f?p=NORMLEXPUB:12100:0::NO::P12100_ILO_ CODE:C011 (accessed on 20 September 2018).

36. ILO. Convention concerning Freedom of Association and Protection of the Right to Organise. Convention 1948 (No. 87). Available online: https://www.ilo.org/dyn/normlex/en/f?p=NORMLEXPUB:12100:::NO:12100: P12100_ILO_CODE:C087:NO (accessed on 20 August 2018).

37. ILO. Rural Workers' Organisations Convention, No. 141. 1975. Available online: https://www.ilo.org/dyn/ normlex/en/f?p=NORMLEXPUB:12100:0::NO::P12100_ILO_CODE:C141 (accessed on 20 August 2018).

38. ILO. Occupational Safety and Health Convention, No. 155. 1981. Available online: https://www.ilo.org/dyn/ normlex/en/f?p=normlexpub:12100:0::no::p12100_instrument_id:312300 (accessed on 23 August 2018).

39. LFT. Ley Federal del Trabajo, Diario Oficial de la Federación; Distrito Federal: México, Mexico, 2015.

40. ISO. ISO 26000. In Guidance on Social Responsibility; International Organization for Standardization: Geneva, Switzerland, 2010.

41. IFC. International Finance Corporation Performance Standar 4. World Bank Group, 2012. Available online: http://www.ifc.org/wps/wcm/connect/topics_ext_content/ifc_external_corporate_site/sustainabilityat-ifc/policies-standards/performance-standards/ps4 (accessed on 30 June 2018).

42. WB. LAC Equity Lab: Poverty. The World Bank, 2017. Available online: http://www.worldbank.org/en/topic/ poverty/lac-equity-lab1/poverty (accessed on 9 October 2017).

43. ILO. Hours of Work (Commerce and Offices) Convention. 1930. No. 30. Available online: https://www.ilo. org/dyn/normlex/en/f?p=NORMLEXPUB:12100:0::NO::P12100_INSTRUMENT_ID:312175 (accessed on 17 August 2018). 
44. ILO. Abolition of Forced Labour Convention. 1957. No. 105. Available online: http://www.ilo.org/dyn/ normlex/en/f?p=NORMLEXPUB:12100:0::NO::P12100_ILO_CODE:C105 (accessed on 25 August 2018).

45. ORC International. Global Perspectives 2015: Worldwide trends in employee engagement. www.ORCInternational.com(Decente et al., n.d.)(Decente et al., n.d.)(Decente et al., n.d.) 2015. Available online: https://orcinternational.com/report/2015-worldwide-trends-in-employee-engagement/ (accessed on 15 October 2018).

46. Suzuki, R.; Shimodaira, H. Pvclust: An R package for assessing the uncertainty in hierarchical clustering. Bioinformatics 2006, 22, 1540-1542. [CrossRef] [PubMed]

47. R Core Team. R: A Language and Environment for Statistical Computing; R Foundation for Statistical Computing: Vienna, Austria, 2016. Available online: https://www.r-project.org/ (accessed on 28 July 2018).

48. INEGI. Censo de población y vivienda 2010. Available online: https://www.inegi.org.mx/programas/ccpv/ 2010/ (accessed on 2 February 2019).

49. ILO. Combating child labour. A handbook for labour inspectors. International Programme on the Elimination of Child Labour (IPEC) InFocus Programme on Safety and Health at Work and the Environment (SafeWork) International Association of Labour Inspection (IALI). 2002. Available online: https://www.ilo.org/global/topics/labour-administration-inspection/resources-library/publications/ WCMS_110148/lang--en/index.htm (accessed on 20 August 2018).

50. HSA. Farm Safety Code of Practice-Risk Assessment Document. Health and Safety Authority, 2006. Available online: https://www.hsa.ie/eng/publications_and_forms/publications/agriculture_and_forestry/ farm_safety_risk_assessment_.pdf (accessed on 10 October 2018).

51. Franze, J.; Ciroth, A. A Comparison of Cut Roses from Ecuador and the Netherlands. Int. J. Life Cycle Assess. 2011, 16, 366-379. [CrossRef]

52. Brandth, B. Gender identity in European family farming: A literature review. Sociol. Rural. 2002, 42, 181-200. [CrossRef]

53. Ballara, M.; Parada, S. El Empleo De Las Mujeres Rurales, 1st ed.; FAO-CEPAL: Rome, Italy, 2009.

54. UN. Transforming our world: The 2030 Agenda for Sustainable Development. In Proceedings of the Seventieth Session of the United Nations General Assembly, New York, NY, USA, 21 October 2015.

55. Hurst, P. Agricultural Workers and Their Contribution to Sustainable Agriculture and Rural Development, 1st ed.; FAO-ILO-IUF. ILO: Geneva, Switzerland, 2007.

56. Kallioniemi, M.K.; Raussi, S.M.; Rautiainen, R.H.; Kymäläinen, H.R. Safety and animal handling practices among women dairy operators. J. Agric. Saf. Health 2011, 17, 63-78. [CrossRef] [PubMed]

57. Contreras, M. Población Rural Y Trabajo En México, 1st ed.; Universidad Nacional Autónoma de México: Ciudad de México, Mexico, 2017.

58. ILO. International Definitions and Prospects of Underemployment Statistics; International Labour Organization: Geneva, Switzerland, 1999. Available online: https://www.ilo.org/global/statistics-and-databases/WCMS_ 091440/lang--en/index.htm (accessed on 6 January 2019).

59. Laca, A.; Mejía, C.; Gondra, J. Propuesta de un modelo para evaluar el bienestar laboral como componente de la salud mental. Psicol. Salud 2006, 16, 87-92.

60. Abrajan, M.G.; Contreras, P.; Montoya, S. Grado de Satisfacción Laboral y Condiciones de Trabajo: Una Exploración Cualitativa. Job satisfaction degree and working conditions: A qualitative exploration. Enseñanza e Investigación en Psicología 2009, 14, 105-118.

61. Acker, J. The effect of organizational conditions (role conflict, role ambiguity, opportunities for professional development, and social support) on job satisfaction and intention to leave among social workers in mental health care. Community Ment. Health J. 2004, 40, 65-73. Available online: https://link.springer.com/article/10. 1023/B:COMH.0000015218.12111.26 (accessed on 20 March 2019). [CrossRef]

62. Siebert, A.; Bezama, A.; O'Keeffe, S.; Thrän, D. Social life cycle assessment indices and indicators to monitor the social implications of wood-based products. J. Clean. Prod. 2018, 172, 4074-4084. [CrossRef]

63. UNHRC. Promotion and Protection of All Human Rights, Civil, Political, Economic, Social and Cultural Rights, Including the Right to Development; United Nations Human Rights Council: Geneva, Switzerlan, 2008. Available online: https://business-humanrights.org/sites/default/files/reports-and-materials/Ruggie-report7-Apr-2008.pdf (accessed on 30 August 2018). 
64. PNUD. Informe Sobre Desarrollo Humano México 2016; México, D.F., Ed.; Programa de las Naciones Unidas para el Desarrollo: New York, NY, USA, 2016. Available online: http://www.mx.undp.org/ (accessed on 15 February 2019).

65. CDI, 2017. Sistema de indicadores sobre la población indígena de México, based on: INEGI, Encuesta Intercensal, México. 2015. Available online: https://www.gob.mx/inpi/documentos/indicadoressocioeconomicos-de-los-pueblos-indigenas-de-mexico-2015 (accessed on 31 January 2019).

66. CONEVAL. Medición de La Pobreza. 2019. Available online: https://www.coneval.org.mx/Medicion/MP/ Paginas/AE_pobreza_2016.aspx, (accessed on 31 January 2019).

67. Dumont, A.; Baret, P. Why working conditions are a key issue of sustainability in agriculture? A comparison between agroecological, organic and conventional vegetable systems. J. Rural. Stud. 2017, 56, 53-64. [CrossRef]

68. OIT. Transición a la formalidad en la economía rural informal. Organización Internacional del Trabajo. 2017. Available online: http://www.ilo.org/global/topics/economic-and-social-development/rural-development/ WCMS_437218/lang--es/index.htm (accessed on 3 February 2019).

69. Yúnez, A.; Taylor, E. The determinants of nonfarm activities and incomes of rural households in Mexico, with emphasis on education. World Dev. 2001, 29, 561-572. [CrossRef]

(C) 2019 by the authors. Licensee MDPI, Basel, Switzerland. This article is an open access article distributed under the terms and conditions of the Creative Commons Attribution (CC BY) license (http://creativecommons.org/licenses/by/4.0/). 